\title{
Structure and dynamics of spruce-beech-fir forests in Nature Reserves of the Orlické hory Mts. in relation to ungulate game
}

\author{
Zdeněk Vacek
}

Czech University of Life Sciences Prague, Faculty of Forestry and Wood Sciences, Kamýcká129, CZ-165 21 Prague, Czech Republic

\begin{abstract}
Knowledge of the structure and dynamics of near-natural mixed forests is a key factor for ecologically oriented management of forest ecosystems. The development of these model forests mostly takes place continually without any pronounced disturbances. Natural regeneration can be locally limited by ungulate browsing. The paper was focused on the structure and development of forest stands with emphasis on natural regeneration in relation to ungulates in Černý důl Nature Reserve and Trčkov National Nature Reserve situated in the Orlické hory Mts., Czech Republic. The case study was conducted in a spruce-beech-fir forest stand on four permanent research plots (PRP) of 0.25 ha in size. PRP are situated in the same stand and in comparable site and stand conditions, but two PRP has been protected against game by fencing since 1985-1989. The stand volume ranged from 478 to $565 \mathrm{~m}^{3} \mathrm{ha}^{-1}$ in age $143-156$ year. The results showed that the diversity of tree layer was higher by $19.8 \%$ ( $48.0 \%$ in species richness) in the stands protected by fence. In the phase of natural regeneration, the species composition, stand structure and number of recruits were poorer on unfenced PRP $\left(7,990\right.$ recruits ha $\left.^{-1}\right)$ compared to fenced PRP $\left(13,160\right.$ recruits ha $\left.^{-1}\right)$. Admixed silver fir and rowan were completely eliminated by browsing (to $94-100 \%$ of individuals). Growth analyses statistically confirmed that ungulates were a significant limiting factor for successful forest development $(\mathrm{P}<0.001)$.
\end{abstract}

Key words: browsing damage; natural regeneration; protected areas; Fagus sylvatica; Picea abies; Abies alba

\section{Introduction}

Natural and semi-natural mixed forests are currently very intensively studied subject (Paluch 2007; Kucbel 2010; Liira et al. 2011; Králíček et al. 2017; Meier et al. 2017). In comparison with managed stands, these forests have many-times higher species diversity (Lindenmayer \& Franklin 2002; Bauhus et al. 2009), self-regulatory ability (Korpel'1995) and stability against external influences (Knoke et al. 2008; Liira et al. 2011).

The ecosystem management in forests of protected areas is based on the highest possible utilization of natural processes (Korpel' 1995; Vacek et al. 2012, 2015). When defining the methods of their care, it is necessary to know how the forest would have spontaneously developed at given sites in the past (Klopcic \& Boncina 2011). It is possible especially only in an original or natural forest where developmental processes not disturbed by primary anthropogenic activities are taking place (Tabaku 2000). In most cases it is admissible or desirable to assist the nature by suitable close-to-nature management (Lindh \& Muir 2004). It will shorten the time to achieve the target situation when the forest can be fully left to spontaneous development in line with the requirements for nature conservation (Bebber et al. 2005; Götmark 2009). But these should not be the systems with a sequence of sustainable practices known from the conventional management of commercial forests (Remeš et al. 2015; Bílek et al. 2015).

Pronounced differences between natural and commercial forests consist not only in management but also in the context of the time dynamics of forest stands. In commercial forests the particular silvicultural practices are strongly focused on wood production (Štefančík et al. 2014; Cukor et al. 2017). Their rotation cycles are usually realized in 25 - 150 -year cycles while developmental cycles in some regions of natural forests can take even thousands of years (Seymour \& Hunter 1999). Mixed forests of European beech (Fagus sylvatica L.), silver fir (Abies alba Mill.) and Norway spruce (Picea abies [L.] Karst.) in the studied nature reserve in the Orlické hory Mts. are characterized by the long developmental cycle lasting for $350-400$ years (Vacek et al. 2014a). It is determined particularly by the lifetime of fir as a tree 
species with the longest longevity. Two generations of beech are accomplished within one generation of fir or spruce (Korpel' 1995).

Forest ecosystems are subjected to temporal changes and various stressors while the temporal stability in response to these external factors is an important aspect of their functions (Mazancourt et al. 2013). The dynamics of natural forests could not continually take place without rather pronounced anthropogenic and biogenic disturbances (Vrška et al. 2009). Nevertheless, disturbances caused by climate extremes, air pollution, bark beetles, windstorms or fires do not avoid natural forests (Borůvka et al. 2005; Zielonka et al. 2010; Král et al. 2015; Bošela et al. 2016). Among these disturbances the ungulates are considered as the most important driver of the metacommunity structure of temperate forests that is able to substantially influence the regeneration process and subsequently the forest development (Senn \& Suter 2003; Suzuki 2013; Mattila \& Kjellander 2017). Due to the slow growth of trees (Ammer 1996) mountain areas are more vulnerable to browsing losses than forests at lower altitudes (Motta 2003). In addition, the red deer (Cervus elaphus L.) population in the studied area is secondarily high. The present hunting management, supporting high population densities of ungulates, is a significant threat to biological diversity of mixed forests (Schulze et al. 2014). Moreover, even low densities of ungulates may have pronounced impacts on natural regeneration, hence on forest development (Jorritsma 1999). In the last decades, a decrease in the fir representation in favour of beech regeneration has been observed in the Krkonoše Mts. and Orlické hory Mts. (Hofmeister et al. 2008; Vacek et al. 2015). A decrease in the percentage of fir due to browsing by game, and also of other tree species preferred by game such as sycamore maple (Acer pseudoplatanus L.), rowan (Sorbus aucuparia L.) European ash (Fraxinus excelsior L.) and beech to a lesser extent, was confirmed also in other areas of central Europe (Motta 2003; Diaci et al. 2010; Konôpka \& Pajtík 2015; Meier et al. 2017). Nevertheless, because of the lack of long-term researches the effects of ungulate impacts on mixed forest stands have been still relatively little known (Vacek et al. 2014a).

The main objective of this paper was to evaluate the structure and development of four forest stands in a fenced and unfenced part of the core area of sprucebeech-fir forest stands in the Černý důl Nature Reserve (NR) and Trčkov National Nature Reserve (NNR) in the Orlické hory Mts. Protected Landscape Area (PLA). The aim were to (1) determine and compare the diversity, structure and production of near-natural mixed forests after 25 - 30 years game-proof fenced enclosure and (2) quantify the influence of ungulates on growth of natural regeneration differentiated by tree species.

\section{Material and Methods}

\subsection{Description of the study area}

The present study was conducted on four permanent research plots (PRP) (GPS 1: 50 $12^{\prime} 05^{\prime \prime} \mathrm{N}, 16^{\circ} 31^{\prime} 10^{\prime \prime} \mathrm{E}$; 2: $\left.50^{\circ} 12^{\prime} 03^{\prime \prime} \mathrm{N}, 16^{\circ} 31^{\prime} 14^{\prime \prime} \mathrm{E}\right)$ situated in the Černý důl NR and two PRP (GPS 3: 50 $0^{\circ} 18^{\prime} 51^{\prime \prime} \mathrm{N}, 1^{\circ} 25^{\prime} 06^{\prime \prime} \mathrm{E}$; 4: $50^{\circ} 18^{\prime} 48^{\prime \prime} \mathrm{N}, 16^{\circ} 25^{\prime} 05^{\prime \prime} \mathrm{E}$ ) in the Trčkov National NNR in the Orlické hory Mts. PLA, west of the frontier between the Czech Republic and Poland (Fig. 1). The protection of this locality was declared in 1954 for Černý důl NR on an area of 26.4 ha, respectively in 1982 for Trčkov NNR on 65.1 ha in order to conserve the autochthonous spruce-fir-beech population at an altitude of 740 $-920 \mathrm{~m}$ a.s.l. Average annual temperature of this locality is $5.5^{\circ} \mathrm{C}$ and annual precipitation amount is around 1000 $-1220 \mathrm{~mm}$. The length of the growing season ranges around 110 days. The bedrock is built of migmatites and orthogneisses, Cambisols are a prevailing soil type.

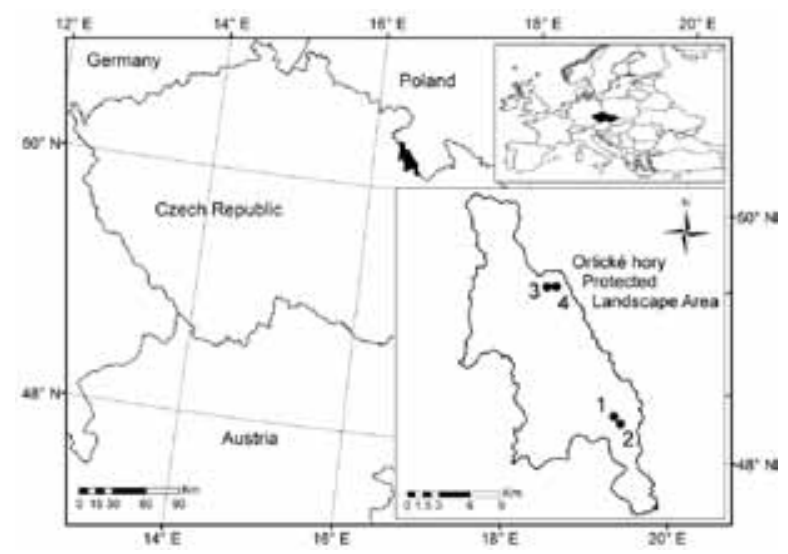

Fig. 1. Localization of autochthonous mixed stands on permanent research plots $1-2$ in the Černý důl Nature Reserve and 3-4 in the Trčkov National Nature Reserve.

A dominant tree species in the reserve is Norway spruce (Picea abies [L.] Karst.; 63.7 - 77.0\%), the percentage of European beech (Fagus sylvatica L.) is 20.5 -33.9\%, of silver fir (Abies alba Mill.) 0.9-1.7\%, while rowan (Sorbus aucuparia L.) and sycamore maple (Acer pseudoplatanus L.) account for less than $1 \%$. The nucleus of the reserve consists of herb-rich to acid beech forests and fir-beech forests belonging to the sub-alliance Acerenion, Eu-Fagenion and the alliance Luzulo-Fagion. The remaining two thirds of the reserve are mostly composed of secondary spruce forests (the alliance Piceion excelsae). Standardized game stocks in the reserves are as follows: 8 - 32 heads of red deer (Cervus elaphus L.), 32 77 head of roe deer (Capreolus capreolus L.) and 16 heads of wild boar (Sus scrofa L.) per 1000 ha. Nevertheless, the actual stock of game is much higher in red deer (51 heads) and wild boar (43 heads). 
PRP are situated in the same forest stand on a moderate slope $\left(11-17^{\circ}\right)$ with an altitude from 795 to $835 \mathrm{~m}$ a.s.l and prevailing north exposure, in similar site and stand conditions. Due to insufficient regeneration, two PRP $(1,3)$ has been protected against game by fencing since 1985-1989. Unfenced PRP $(2,4)$ are located at $5-15 \mathrm{~m}$ outside the game-proof fenced enclosure. According to the Czech typological system it is forest type 6S - fresh spruce-beech forests (Piceeto-Fagetum oligomesotrophicum). The age of the particular tree layers on PRP is comparable: 49-56/102-113/187-195.

\subsection{Data collection}

Field-Map technology (IFER - Monitoring and Mapping Solutions Ltd.) was used to establish PRP of $50 \times 50 \mathrm{~m}$ in size ( $0.25 \mathrm{ha})$. The measured characteristics on a tree layer were position, crown projection, diameter at breast height (dbh $\geq 4 \mathrm{~cm}$; accuracy to $1 \mathrm{~mm}$ ), tree height and distance of live crown base to the ground level (accuracy to $0.1 \mathrm{~m}$ ). The position, crown height and width were measured in natural regeneration $(\mathrm{h} \geq 50 \mathrm{~cm}, \mathrm{dbh}<4 \mathrm{~cm}$ ). Damage by browsing were investigated in all recruits by tree species on unfenced PRP. In juvenile stages stem samples were taken for growth analyses, five samples in the game-proof enclosure and outside this enclosure in the proximity of PRP. The height of recruits and their age were determined in 5-cm sections.

\subsection{Data analysis}

Basic stand characteristics were quantified from recorded dendrometric data for the tree layer. Tree volume was calculated by using volume equations published by Petráš \& Pajtík (1991). To assess the stand diversity the following indices were computed by software Sibyla 5 (Fabrika et al.): Arten-profile index (Pretzsch 2001), diameter and height differentiation index (Füldner 1995), species diversity index (Shannon 1948), species evenness index (Pielou 1975), species richness index (Menhinick 1964) and total diversity index (Jaehne \& Dohrenbusch 1997).

In all individuals of natural regeneration and tree layer the spatial distribution was evaluated according to index of non-randomness (Pielou 1959; Mountford
1961), aggregation index (Clark \& Evans 1954), index of cluster size (David \& Moore 1954) and Ripley's $L$-function (Ripley 1981). The criteria of diversity indices are shown in Table 1. The software PointPro 2 (Zahradnik $\&$ Pus) programme was used for the computation of horizontal structure. The test of significance of the deviations from the values expected for a random point pattern was done by Monte Carlo simulations. The mean values of $L$-function were estimated as averages of $L$-functions computed for 1999 randomly generated points. Along with the measurements of horizontal structure on the PRPs, stand density, crown projections area and crown closure were also calculated.

Situational maps were created in the ArcGIS 10 programme (Esri). Statistical analyses were processed in the Statistica 13 software (StatSoft, Tulsa). Data were logarithmized to obtain the normal distribution and tested by the Kolmogorov-Smirnov test. Differences in species diversity, frequencies of height and diameter classes between PRP and also in the mean height of recruits damaged by browsing and those with normal growth without browsing were tested by one-way analysis of variance (ANOVA). Significant differences were consequently tested by post-hoc Tukey test.

\section{Results}

\subsection{Tree layer biodiversity}

In the framework of species diversity, richness $(D ; \mathrm{X}$ $=0.454, \mathrm{SD}= \pm 0.096)$ and heterogeneity $\left(H^{\prime} ; 0.373\right.$, \pm 0.061 ) showed medium diversity (Table 2 ), respectively evenness reached rich diversity $(E ; 0.665, \pm 0.138)$. The vertical structure composed mainly of three storeys was highly diversified on these plots $(A ; 0.680, \pm 0.087)$, especially on fenced PRP 1 close to selection structure. Height and diameter differentiation indicated forest stands with high structural differentiation on fenced PRP (TM; $0.500, \pm 0.034$ ) or medium on control unfenced PRP (TM; $0.405, \pm 0.024)$. From the aspect of total diversity, there was very diverse structured stand on fenced PRP 1 , a diverse structure was typical for forest stands on PRP 2 and 3 and structure on unfenced PRP 4 was uneven (Table 2). In all the above-mentioned cases, with the exception of species evenness (lower by $11.9 \%$ due to

Table 1. Overview of indices describing the biodiversity and their common interpretation.

\begin{tabular}{|c|c|c|c|c|}
\hline Criterion & Quantifiers & Label & Reference & Evaluation \\
\hline \multirow{3}{*}{ Horizontal structure } & Index of non-randomness & $\alpha(\mathrm{P} \& \mathrm{Mi})$ & Pielou (1959); Mountford (1961) & mean value $\alpha=1$; aggregation $\alpha>1$; regularity $\alpha<1$ \\
\hline & Aggregation index & $R(\mathrm{C} \& \mathrm{Ei})$ & Clark \& Evans (1954) & mean value $R=1$; aggregation $R<1$; regularity $R>1$ \\
\hline & Index of cluster size & $\operatorname{ICS}(\mathrm{D} \& \mathrm{Mi})$ & David \& Moore 1954 & mean value $I C S=0$; aggregation $I C S>0$; regularity $I C S<0$ \\
\hline Vertical diversity & Arten-profile index & $A(\mathrm{Pi})$ & Pretzsch (2001) & $\begin{array}{l}\text { range } 0-1 \text {; balanced vertical structure } A<0.3 \text {; } \\
\text { selection forest } A>0.9\end{array}$ \\
\hline Structural differentiation & $\begin{array}{l}\text { Diameter dif. } \\
\text { Height dif. }\end{array}$ & $\begin{array}{l}T M_{d}(\mathrm{Fi}) \\
T M_{h}(\mathrm{Fi})\end{array}$ & Füldner (1995) & range $0-1$; low $T M<0.3$; very high differentiation $T M>0.7$ \\
\hline \multirow{3}{*}{ Species diversity } & Heterogeneity & $H^{\prime}(\mathrm{Si})$ & Shannon (1948) & minimum $H^{\prime}=0$, higher $H^{\prime}=$ higher values \\
\hline & Evenness & $E(\mathrm{Pi})$ & Pielou (1975) & range $0-1 ;$ minimum $E=0$, maximum $E=1$ \\
\hline & Richness & $D(\mathrm{Mi})$ & Menhinick (1964) & minimum $D=0$, higher $D=$ higher values \\
\hline Complex diversity & Stand diversity & $B(J \& D i)$ & Jaehne \& Dohrenbusch (1997) & $\begin{array}{l}\text { monotonous structure } B<4 \text {; uneven structure } B=6-8 \text {; } \\
\text { very diverse structure } B>9\end{array}$ \\
\hline
\end{tabular}


more tree species), the studied structural indices were more favourable on fenced plots compared to control plots. A comparison of both type of PRP showed that the biodiversity (without aggregation indices) was in average higher by $19.8 \%$ in the stands protected by fencing after
25 - 30 years (in 2014), respectively there were significant differences $\left(\mathrm{F}_{(1,26)}=4.18, \mathrm{P}<0.05\right)$ excluding species evenness. The highest positive differences were observed in tree species richness (48.0\%) and height differentiation $(26.0 \%)$.

Table 2. Indices describing the diversity of tree layer of mixed stand on permanent research plots $1-4$.

\begin{tabular}{lcccccccccc}
\hline PRP & $D(\mathrm{Mi})$ & $H^{\prime}(\mathrm{Si})$ & $E(\mathrm{Pi})$ & $A(\mathrm{Pi})$ & $T M_{d}(\mathrm{Fi})$ & $T M_{h}(\mathrm{Fi})$ & $R(\mathrm{C} \& \mathrm{Ei})$ & $\alpha(\mathrm{P} \& \mathrm{Mi})$ & $I C S(\mathrm{D} \& \mathrm{Mi})$ & $B(\mathrm{~J} \& \mathrm{Di})$ \\
\hline 1 & 0.478 & 0.448 & 0.773 & 0.789 & 0.549 & 0.513 & 0.936 & 1.195 & 0.186 & 9.382 \\
2 & 0.427 & 0.399 & 0.820 & 0.737 & 0.428 & 0.366 & 1.035 & 1.179 & 0.110 & 8.202 \\
3 & 0.589 & 0.366 & 0.481 & 0.615 & 0.474 & 0.463 & 1.068 & 1.232 & 0.035 \\
4 & 0.320 & 0.280 & 0.587 & 0.577 & 0.415 & 0.414 & 1.042 & 1.085 & -0.246 \\
\hline
\end{tabular}

Explanatory notes: $D$ - index of species richness, $H^{\prime}$ - index of species heterogenity, $E$ - index of species evenness, $A$ - Arten-profile index, $T M_{d}-$ diameter differentiation index, $T M_{h}-$ height differentiation index, $R$-aggregation index, $\alpha$-index of non-randomness, ICS - index of cluster size, $B$ - total diversity index.

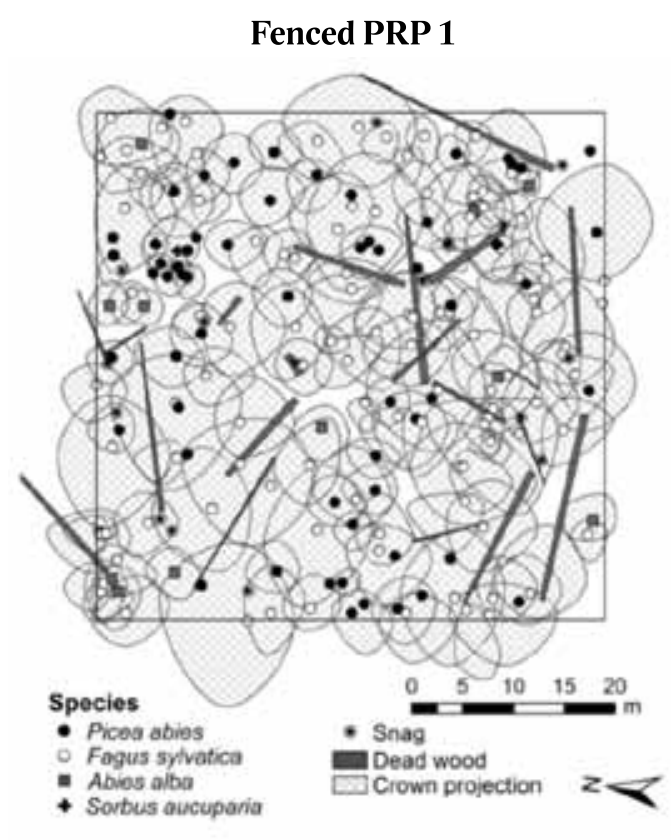

Fenced PRP 3

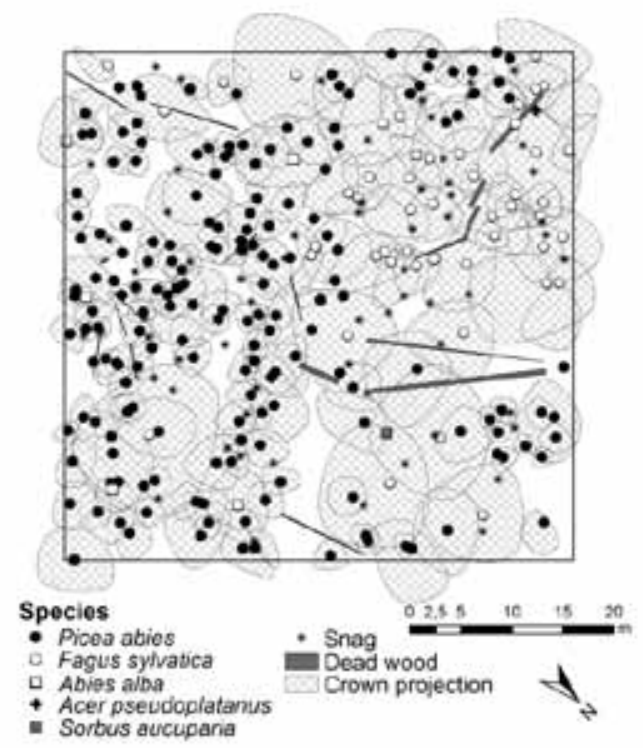

Unfenced PRP 2

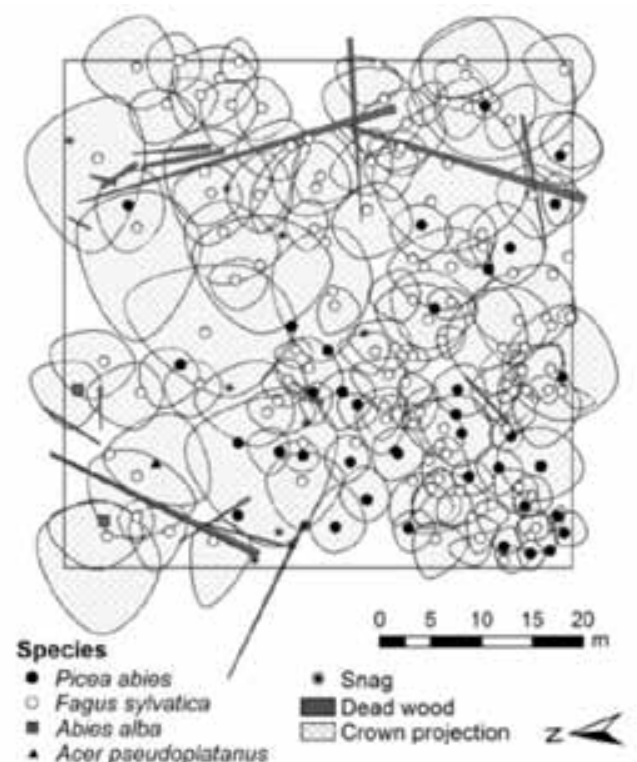

Unfenced PRP 4

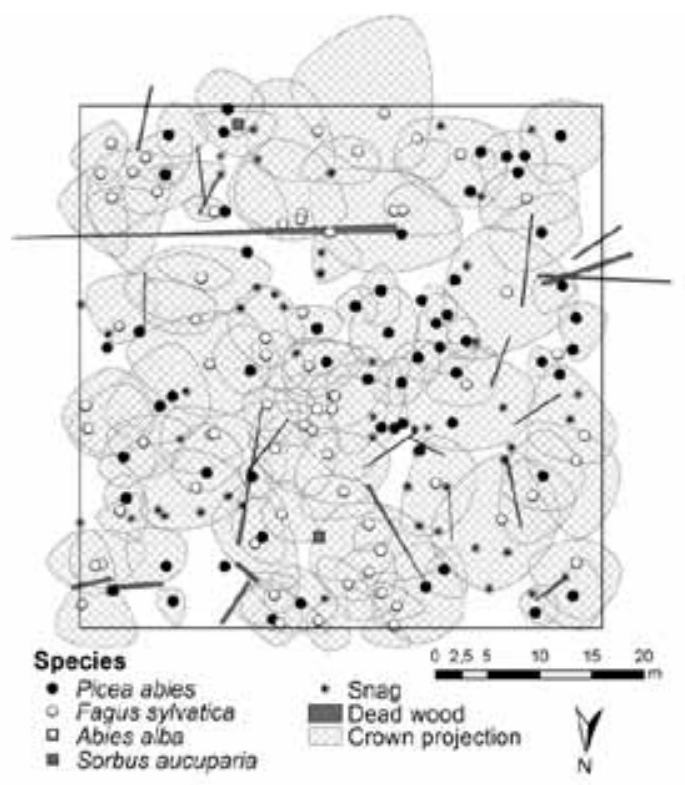

Fig. 2. Horizontal structure of the tree layer of mixed forest on permanent research plots 1-4. 
The horizontal structure of tree layer was random on fenced PRP (Fig. 2) according to computed structural indices (Table 2). Based on $L$-function, the random distribution of tree layer individuals was revealed within a spacing (distance) to $3-4 \mathrm{~m}$, farther it was aggregated. Concretely the analysis of individuals of the overstorey $(\mathrm{h}>20 \mathrm{~m}$ ) showed their prevailing random distribution $(\alpha=0.05)$. Aggregation was typical of the understorey, only on PRP 1 the $R$ index showed a random structure. In the understorey the distribution of individuals was random to a distance around $2 \mathrm{~m}$ while it was aggregated at a larger spacing. The distribution of all individuals of tree layer on unfenced control PRP was random (Fig. 3, Table 2). The overstorey pattern was regular by $R$ and ICS indices while it was random by the $\alpha$ index on PRP 2. Aggregation was found out in the lower tree layer similarly like in fenced PRP but it was far from being so pronounced (a lower number of individuals growing up to the registration boundary). Based on $L$-function, the regular distribution of overstorey individuals was revealed within a spacing to $6 \mathrm{~m}$, farther it was random. The spatial pattern of intermediate and suppressed individuals was random to a distance of $1 \mathrm{~m}$, and clumpy at a larger spacing. Differentiation according to tree species on all

\section{Fenced PRP 1}

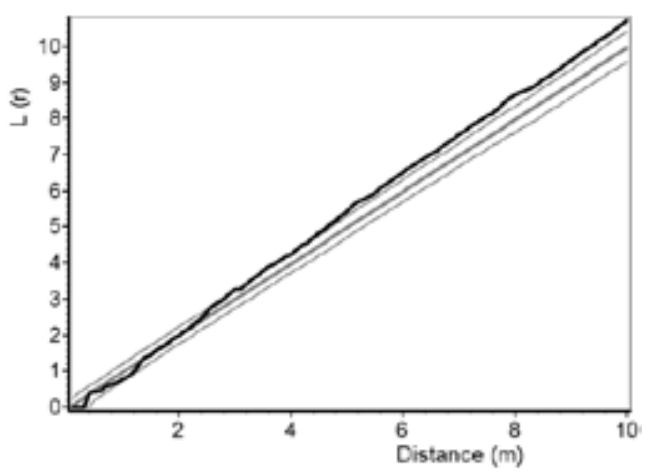

Fenced PRP 3

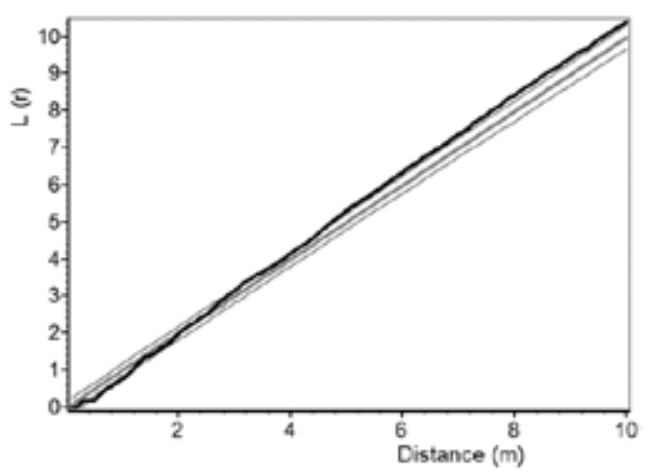

PRP shows the random distribution of spruce and beech by all above-mentioned indices, respectively the spruce had a tendency toward aggregation in smaller spacing.

\subsection{Stand structure and production}

The stand density index (SDI) of tree layer on fenced PRP was 0.74 , the area of crown projections amounted to 3.91 ha and canopy cover was 0.92 . The stand volume ranged $478-558 \mathrm{~m}^{3} \mathrm{ha}^{-1}$ (spruce $46-73 \%$, beech 15 $-38 \%$, fir $12-16 \%$, rowan and sycamore $<1 \%$; Table $3)$. The number of tree layer individuals was 816 trees $\mathrm{ha}^{-1}$ and basal area was $47.6 \mathrm{~m}^{2} \mathrm{ha}^{-1}$ in average. Periodic annual increment in 2014 was $7.5 \mathrm{~m}^{3} \mathrm{ha}^{-1} \mathrm{y}^{-1}$ and mean annual increment $3.5 \mathrm{~m}^{3} \mathrm{ha}^{-1} \mathrm{y}^{-1}$. SDI on unfenced PRP was lower by $11 \%(0.66)$ and the area of crown projections by $29 \%$ ( $2.78 \mathrm{ha}$ ), but the canopy cover was similar (0.93) compared to fenced PRP. The higher stand volume reached $559 \mathrm{~m}^{3} \mathrm{ha}^{-1}$ (spruce $37-73 \%$, beech $27-53 \%$, fir $9 \%$, sycamore and maple $<1 \%$ ). The number of tree layer individuals was 516 trees ha $^{-1}$, that it is difference by $25 \%$ compared to fenced PRP, but mean basal area was only by $2 \mathrm{~m}^{3} \mathrm{ha}^{-1}$ lower. Periodic annual increment in 2014 was $6.5 \mathrm{~m}^{3} \mathrm{ha}^{-1} \mathrm{y}^{-1}$ and mean annual increment $3.7 \mathrm{~m}^{3} \mathrm{ha}^{-1} \mathrm{y}^{-1}$.

\section{Unfenced PRP 2}

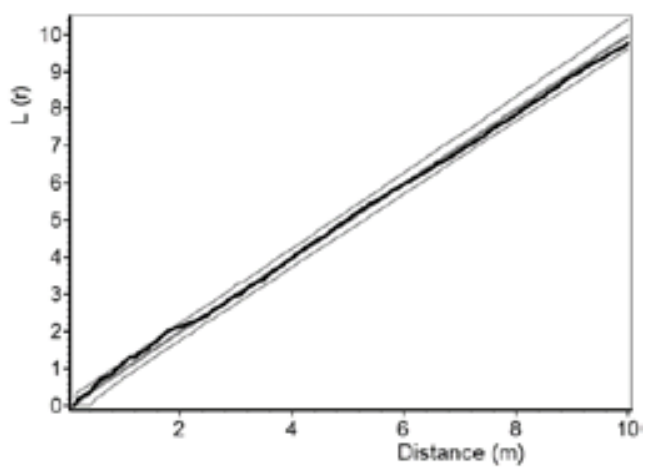

Unfenced PRP 4

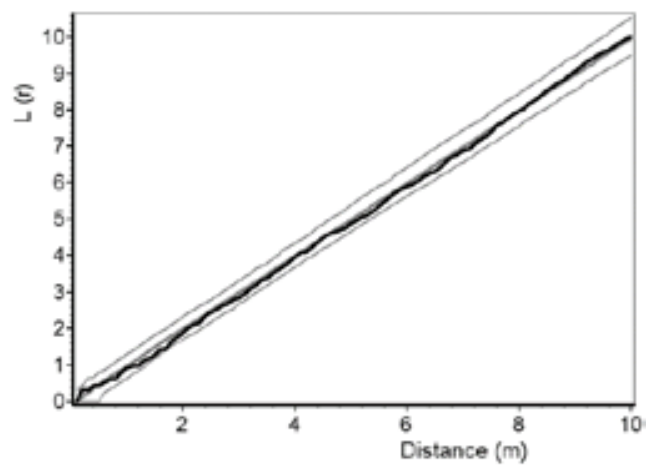

Fig. 3. Spatial pattern of mixed stand on permanent research plots $1-4$ expressed by $L$-function; the black line represents the $L$-function for real distances of trees; the bold gray line represents the mean course for random spatial distribution and the two thinner central curves represent 95\% interval of reliability; when the black line of tree distribution on the PRP is below (under) this interval, it indicates a tendency of trees toward regular (aggregation) distribution. 
Table 3. Overview of stand parameters of mixed stand on permanent research plots 1-4.

\begin{tabular}{|c|c|c|c|c|c|c|c|c|c|c|c|c|}
\hline \multirow{2}{*}{ PRP } & \multirow{2}{*}{$\begin{array}{c}\mathrm{t} \\
{[\mathrm{y}]}\end{array}$} & \multirow{2}{*}{$\begin{array}{c}\mathrm{dbh} \pm \mathrm{SD} \\
{[\mathrm{cm}]}\end{array}$} & $\mathrm{h}$ & $\mathrm{h}_{95}$ & \multirow{2}{*}{ f } & \multirow{2}{*}{$\begin{array}{c}\mathrm{v} \\
{\left[\mathrm{m}^{3}\right]}\end{array}$} & \multirow{2}{*}{$\begin{array}{c}\mathrm{N} \\
{\left[\text { trees ha }{ }^{-1}\right]}\end{array}$} & \multirow{2}{*}{$\begin{array}{c}\mathrm{G} \\
{\left[\mathrm{m}^{2} \mathrm{ha}^{-1}\right]}\end{array}$} & \multirow{2}{*}{$\begin{array}{c}\mathrm{V} \\
{\left[\mathrm{m}^{3} \mathrm{ha}^{-1}\right]}\end{array}$} & \multirow{2}{*}{ HDR } & PAI & MA \\
\hline & & & \multicolumn{2}{|c|}{$[\mathrm{m}]$} & & & & & & & \multicolumn{2}{|c|}{$\left[\mathrm{m}^{3} \mathrm{ha}^{-1} \mathrm{y}^{-1}\right]$} \\
\hline \multicolumn{13}{|c|}{ Picea abies } \\
\hline 1 & 147 & $34.1 \pm 19.7$ & 16.34 & 31.9 & 0.613 & 0.914 & 240 & 21.8 & 220 & 47.9 & 2.75 & 1.50 \\
\hline 2 & 156 & $38.1 \pm 24.5$ & 17.30 & 38.7 & 0.657 & 1.295 & 160 & 18.0 & 207 & 45.4 & 2.10 & 1.33 \\
\hline 3 & 156 & $25.5 \pm 17.0$ & 13.01 & 35.5 & 0.868 & 0.577 & 708 & 36.2 & 408 & 51.0 & 5.10 & 2.62 \\
\hline 4 & 165 & $41.6 \pm 25.6$ & 18.66 & 43.0 & 0.657 & 1.667 & 240 & 32.4 & 400 & 44.9 & 4.40 & 2.42 \\
\hline \multicolumn{13}{|c|}{ Fagus sylvatica } \\
\hline 1 & 126 & $22.6 \pm 14.8$ & 12.07 & 27.7 & 0.889 & 0.430 & 420 & 16.8 & 181 & 53.4 & 3.45 & 1.44 \\
\hline 2 & 140 & $25.5 \pm 18.5$ & 13.14 & 31.0 & 1.001 & 0.675 & 444 & 22.7 & 300 & 51.5 & 3.45 & 2.14 \\
\hline 3 & 119 & $24.1 \pm 12.8$ & 17.67 & 26.1 & 0.544 & 0.439 & 192 & 8.7 & 84 & 73.3 & 1.65 & 0.71 \\
\hline 4 & 131 & $25.3 \pm 13.5$ & 17.67 & 29.5 & 0.625 & 0.555 & 272 & 13.6 & 151 & 69.8 & 2.35 & 1.21 \\
\hline \multicolumn{13}{|c|}{ Abies alba } \\
\hline 1 & 169 & $48.2 \pm 29.5$ & 17.60 & 32.8 & 0.607 & 1.948 & 40 & 7.0 & 78 & 36.5 & 1.20 & 0.46 \\
\hline 2 & 170 & $73.9 \pm 9.8$ & 36.85 & 38.2 & 0.399 & 6.299 & 8 & 3.4 & 50 & 49.9 & 0.55 & 0.29 \\
\hline 3 & 181 & $55.8 \pm 30.8$ & 24.96 & 36.9 & 0.529 & 3.229 & 20 & 4.5 & 65 & 44.7 & 0.80 & 0.36 \\
\hline \multicolumn{13}{|c|}{ Total } \\
\hline 1 & 143 & $28.7 \pm 18.7$ & 13.80 & 30.4 & 0.761 & 0.679 & 704 & 45.6 & 478 & 48.1 & 7.45 & 3.35 \\
\hline 2 & 148 & $30.4 \pm 21.5$ & 14.61 & 35.1 & 0.865 & 0.916 & 616 & 44.7 & 565 & 48.1 & 6.15 & 3.82 \\
\hline 3 & 153 & $26.1 \pm 16.9$ & 14.20 & 32.5 & 0.791 & 0.601 & 928 & 49.6 & 558 & 54.4 & 7.55 & 3.64 \\
\hline 4 & 156 & $33.7 \pm 20.7$ & 18.05 & 38.5 & 0.659 & 1.062 & 520 & 46.4 & 552 & 53.6 & 6.75 & 3.54 \\
\hline
\end{tabular}

Explanatory notes: $t$ - average stand age; $d b h \pm S D$ - mean quadratic dbh \pm standard deviation; $h$ - mean height; $h_{95}$-top $95 \%$ height; $f$-form factor; $v$-average tree volume; $N$-number of trees per hectare; $G$ - basal area; $V$-stand volume; $H D R$ - slenderness quotient; $P A I$ - periodic annual increment; $M A I$ - mean annual increment.

On fenced PRP the representation of diameter classes showed a left-sided pattern and generally corresponded to the shape of Liocourt curve (compared to unfenced PRP) with the highest frequency in the $4-12 \mathrm{~cm}$ classes. On PRP 1 spruce representation in diameter classes was uneven, and the beech diameter structure also indicated the curve of an optimum structure of selection forest. Reverse situation was on PRP 3. Interspersed fir as 20 -40 trees ha $^{-1}$ occurred in diameter class 1 and then in the diameter range of $44-80 \mathrm{~cm}$ (the advanced growing-

\section{Fenced PRP 1}

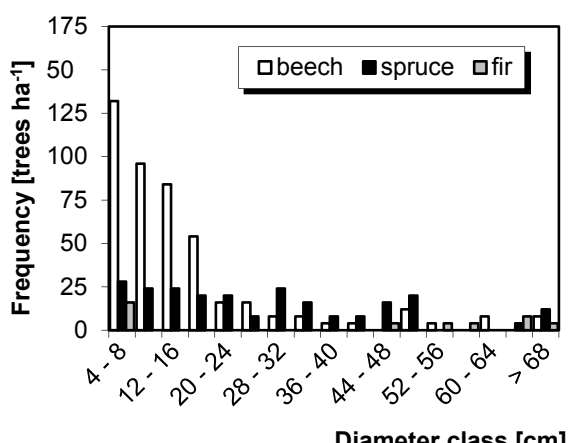

Fenced PRP 3

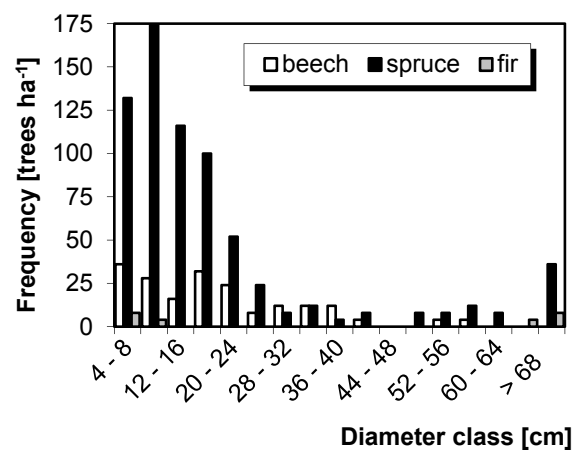

up stage was completely missing there). Fir and spruce make up the overstorey with maximum height of 36.9 and $40.3 \mathrm{~m}$, respectively. In unfenced PRP, similarly like in PRP 1 and 3, a geometrically decreasing tendency was found out in diameter classes, but not so relevant (especially on PRP 4; Fig. 4). Spruce dominant position was documented by a maximum height of $44.5 \mathrm{~m}$. Mean $\mathrm{dbh}$ on fenced PRP was $27.4 \mathrm{~cm}( \pm 17.8)$ while on unfenced PRP it was higher by $4.7 \mathrm{~cm}(32.1 \mathrm{~cm}, \pm 21.1)$. The recruits of fir, sycamore and rowan not reach the registration boundary due to missing of advanced natural

Unfenced PRP 2

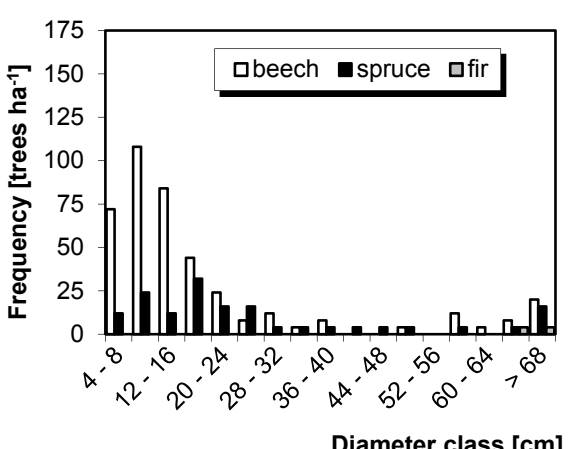

Unfenced PRP 4

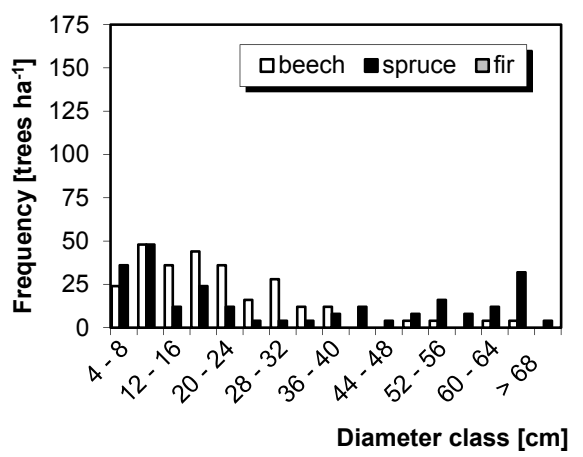

Fig. 4. Frequency of diameter classes of tree layer differentiated by main species on permanent research plots 1-4 in 2014. 
regeneration. A comparison of the average frequencies of all individuals on both PRP in the initial diameter classes suggests a statistically significant difference $\left(\mathrm{F}_{(1,18)}=4.3, \mathrm{P}<0.05\right)$ in favour of fenced stands.

\subsection{Natural regeneration and damage by game}

On fenced PRP, in advance growth $(\mathrm{h} \geq 50 \mathrm{~cm})$ there were 24,468 individuals of natural regeneration (beech $77 \%$, spruce $17 \%$, fir $3 \%$ and rowan $3 \%$ ) on PRP 1 and 1,852 recruits (spruce $58 \%$, beech $21 \%$, fir $16 \%$ and rowan $5 \%$ ) on PRP 3. Natural regeneration with distinct height and diameter differentiation was produced there as a result of the minimum pressure of ungulates (Fig. 5). The height structure of natural regeneration showed a leftsided pattern and by their height the majority of the trees belonged to the $50-60 \mathrm{~cm}$ class. The spatial distribution of natural regeneration was significantly aggregated on all plots $(\alpha=0.05)$ with higher tendency of clumpiness on unfenced PRP. On unfenced PRP 2 there were in total 15,292 recruits ha ${ }^{-1}$ as advance growth recruits (beech $95 \%$, spruce $5 \%$, rowan $<1 \%$ ), while fir did not reach the height of $50 \mathrm{~cm}$. On PRP 4 number of recruits was 688 recruits ha $^{-1}$ (spruce $53 \%$, beech $40 \%$, rowan $4 \%$, fir 3\%).

A comparison of the height structure on PRP 1 and 2 showed that the average frequency of recruits in all height classes was similar $\left(\mathrm{F}_{(1,24)}=1.0, \mathrm{P}>0.05\right)$, but the frequency of recruits exceeding the height of $100 \mathrm{~cm}$ was demonstrably higher on fenced PRP $1\left(\mathrm{~F}_{(1,14)}=7.3\right.$, $\mathrm{P}<0.05)$. On PRP 2 recruits higher than $100 \mathrm{~cm}$ account only for $1.2 \%$ of the total number (180 recruits ha $\left.{ }^{-1}\right)$, on PRP 1 it was $22.5 \%$ (5,512 recruits $\left.^{-1}{ }^{-1}\right)$, i.e. 30.6 times more, but in the total number only 1.6 times more. Compared PRP 3 and 4 , it was 2.7 times higher total number on the fenced PRP. On fenced PRP 3 recruits higher than $190 \mathrm{~cm}$ (grow up from game browsing) was $40.1 \%$ (364 recruits ha ${ }^{-1}$ ), while on unfenced PRP 4 only $11.3 \%$ (40 recruits ha ${ }^{-1}$ ) due to the strong pressure of game. Compared locality Černý důl, the mean height of all

Černý důl

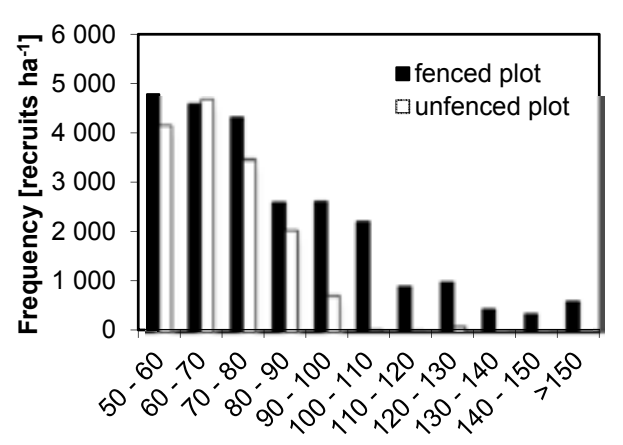

individuals was significantly higher $\left(\mathrm{F}_{(1,39758)}=1016.3\right.$, $\mathrm{P}<0.001)$ on PRP $1(\mathrm{X}=82.7, \mathrm{SE} \pm 0.3)$ than on PRP $2(68.6 \mathrm{~cm}, \pm 0.3)$. Similar situation was in Trčkov $\left(\mathrm{F}_{(1,2538)}=407.3, \mathrm{P}<0.001\right)$. The greatest damage by browsing was caused to fir (browsing in $100 \%$ of recruits) and rowan (in $94 \%$ of recruits). Beech was damaged to a smaller extent (in $56 \%$ of recruits) and the smallest damage was observed in spruce (in $18 \%$ of recruits). Natural regeneration of sycamore maple was completely browsed by brown hare (Lepus europaeus Pallas).

A comparison of the mean heights of individuals in the game-proof fenced enclosure and the heights reduced by browsing outside (Fig. 6) showed a significant influence of ungulates $\left(F_{(1,98)}=39.5, P<0.001\right)$. At the juvenile stage (ca. under 5 years) the studied tree species was not significantly damaged by game $\left(\mathrm{F}_{(1,18)}=2.7\right.$, $P>0.05)$. As soon as they exceed the height of the herb layer, they are exposed to regular browsing and they nearly stop growing. A difference in height at the age of 10 years was already statistically significant $\left(\mathrm{F}_{(1,18)}=81.3\right.$, $\mathrm{P}<0.001)$. For instance, in the Černý důl NR beech at 20 years of age on the fenced plot had the mean height of 211 $\mathrm{cm}( \pm 13)$, but with heavy browsing by game its height was only $73 \mathrm{~cm}( \pm 15)$, i.e. $34 \%$ of the current height (in spruce 29\%). Fir and rowan were not analysed because of their limited number in this locality. In Trčkov NNR fir at 20 years of age on the fenced plot had the mean height of $224 \mathrm{~cm} \mathrm{(} \pm 7)$, but with repeated browsing its height was only $63 \mathrm{~cm}( \pm 9)$, i.e. $28 \%$ of the current height (in beech $32 \%$, in spruce $49 \%$ ). The highest damages differences were observed in fir.

\section{Discussion}

Changes in species composition and structure are the basic component of forest dynamics (Fürst et al. 2007; Klopcic \& Boncina 2011), but in the last several centuries (Linder \& Östlund 1998). These factors include unfavourable development of ungulate game population and high damage to forests. Game management is often preferred over forestry (Ambrož et al. 2015; Konôpka et al.

Trčkov

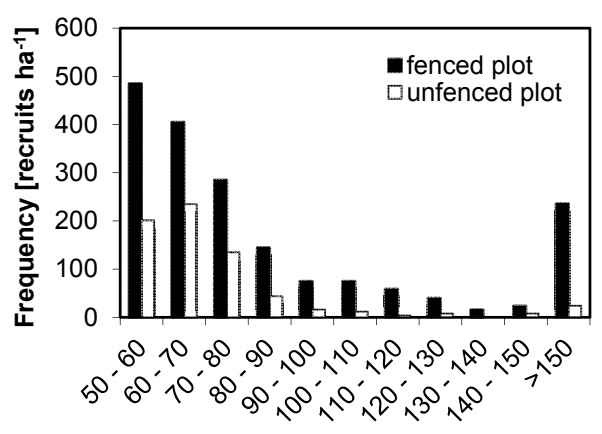

Fig. 5. Frequency of height structure of natural regeneration per hectare on reserves Černý důl and Trčkov (fenced plots 1,3 ; unfenced plots 2,4). 

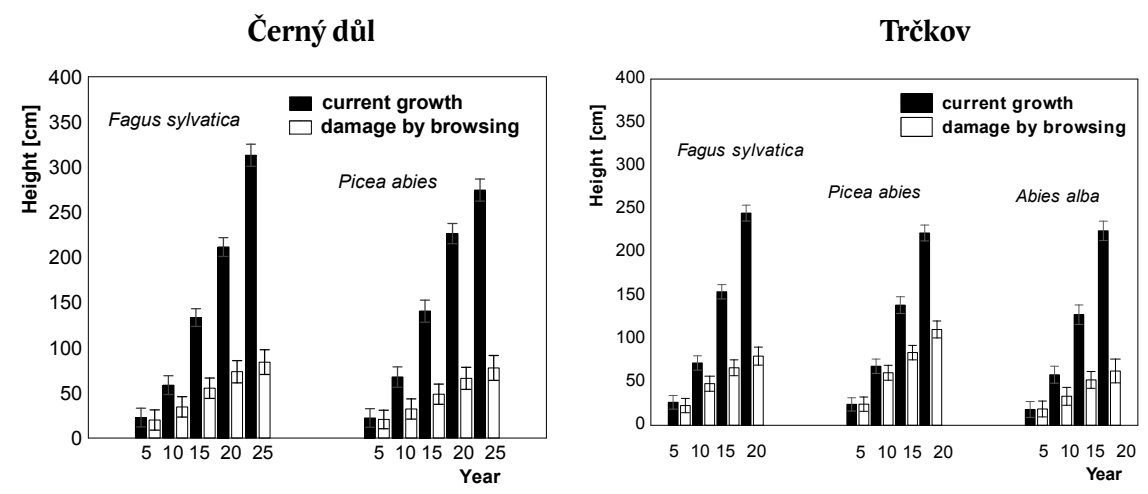

Fig. 6. Development of mean height growth of recruits (average values of current trend in comparison with decreased growth due to browsing), error bars indicate standard errors.

2015), that it leads to disproportionate damage by browsing in stands, especially in terms of a natural regeneration failure. The development of near-natural mixed sprucefir-beech forests may however take place only without any stronger anthropogenic disturbances (Vrška et al. 2009). Research on the structure and development of mixed forests in the Orlické hory Mts. has been conducted since 1951 (Vacek et al. 2017a). The present research plots comprise mountain spruce-beech-fir forests with the species composition near-natural forests (beech 55\%, spruce $33 \%$, fir $12 \%$ ), representing an optimum model of forest stand for the fulfilment of various functions and being extraordinarily resistant to disturbances (Ammer 1996). Nevertheless, these forests have been influenced quite substantially to the detriment of fir (Hofmeister et al. 2008) and by high population densities of ungulates (Vacek et al. 2014a).

The spatial distribution of parent stand trees on the studied PRP documented a random pattern similarly like in natural spruce-fir forests in the Carpathian Mts. (Paluch 2007), mixed forests in Lower Austria (Splechtna et al. 2005) or mixed forests of the Boubín virgin forest (Šebková et al. 2011). Spatial analyses showed that the overstorey was distributed randomly with a tendency toward regularity but the trees in lower storeys showed a clumpy pattern. According to others studies from Central Europe significant clumpiness occurred in small trees but large trees showed a regular pattern while the horizontal structure of parent stand was random in general (Szwagrzyk \& Czerwczak 1993; Bílek et al. 2011). On fenced PRP a higher tendency toward aggregation was observed in the lower storey which is a result of the successful growth of clumpy natural regeneration in the crown canopy gaps (Zeibig et al. 2005). Natural regeneration was strongly aggregated, especially on unfenced plots due to lower number of recruits, that it corresponds with other researches from Sudetes Mts. (Vacek et al. 2014b; Bulušek et al. 2016).

On both plots there are the autochthonous sprucefir-beech stand with rich high spatial and age differentiation, which is composed of three layers sometimes inter- mingling with each other to create the almost selection structure, especially on fenced plots. In Poland in the Bieszczady National Park similar stands were described by Jaworski et al. (2002) or in the Karkonoski Park Narodowy by Vacek et al. (2010). After 25 - 30 of protection by fencing, structural and species diversity were significantly more favourable on fenced plots compared to control plots. The highest differences reached in species richness and height differentiation in favor of the fenced stands. Very diverse structure of fenced forest stand was also observed from other research in the Trčkov NNR (B; index 8.61) compared to lower complex diversity in unfenced stand (B; 7.66; Vacek et al. 2013), such as in other mixed not fenced spruce-beech forest in Orlické hory Mts. (B 6.57 - 8.05; Králíček et al. 2017). Study forest stands with pronounced age, spatial and species differentiation are generally considered as ecologically stable (Klopcic \& Boncina 2011).

Breast height diameter of trees was considered by Nilsson et al. (2002) as one of the important features of old near-natural forest stands. PRP comply with the reference value of $10-20$ trees ha ${ }^{-1}$ with $\mathrm{dbh}>70 \mathrm{~cm}$. The fir occurred mainly in large diameter classes while smaller dimensions prevail in beech. The trend of fir representation is very negative for further development (Klopcic et al. 2010) because it may lead to the suppression of fir trees in forest stands for a long time (Ferlin 2002). An evident decrease in fir in mixed forests was observed also in Slovakia (Štefančík 2006; Saniga et al. 2013) and in other areas (Vrška et al. 2009; Ficko et al. 2010). Different results were reported by Paluch (2007) from near-natural mixed forests in the Carpathian Mts., where the fir had higher representation in lower diameter classes. High share of fir in juvenile development phases was observed in Tyrol or Krkonoše Mts., but it was caused also due to protection by fencing (Vacek et al. 2015; Meier et al. 2017). The trend of spruce representation in diameter classes was similar at the compared localities. The stand volume on PRP ranged between $478 \mathrm{~m}^{3} \mathrm{ha}^{-1}$ and $565 \mathrm{~m}^{3} \mathrm{ha}^{-1}$, respectively. If compared with the Belevine locality in Croatia as reported by Čavlovič et 
al. (2006), the stand volume on PRP 2 was much higher (by $\left.161 \mathrm{~m}^{3} \mathrm{ha}^{-1}\right)$, and similar values $\left(543 \mathrm{~m}^{3} \mathrm{ha}^{-1}\right)$ were reported by Paluch (2007). Higher values found Saniga (1999) in Slovak old-growth Dobročský forest, which consists of spruce, fir, beech and sycamore $(600-$ $\left.853 \mathrm{~m}^{3} \mathrm{ha}^{-1}\right)$. Distinctly higher stand volumes were also reached by mixed stands in the Serbian reserve Račanska Šljivovica, where the stand volume was $800 \mathrm{~m}^{3} \mathrm{ha}^{-1}$. In addition, the stand volume in this reserve has been slightly increasing in the last years (Pantič et al. 2011), and so its trend was similar to that expected on the studied PRP. Contrary to the stand volume, the basal area on the particular PRP was almost identical $\left(47 \mathrm{~m}^{2} \mathrm{ha}^{-1} \pm 2\right)$. In comparison with the basal area from forest stands in Belevine in Croatia (Čavlovič et al. 2006), the basal area was higher by $26 \%$ while the lower value $\left(36 \mathrm{~m}^{2} \mathrm{ha}^{-1}\right)$ was reported by Paluch (2007) from near-natural forests in the West Carpathians.

The total number of recruits from natural regeneration $(\mathrm{h} \geq 50 \mathrm{~cm})$ was lower by $38 \%$ on unfenced PRP $2\left(15,292\right.$ recruits ha $\left.^{-1}\right)$ compared to fenced PRP 1 $\left(24,468\right.$ recruits ha $\left.{ }^{-1}\right)$ but the abundance of recruits exceeding the height $\geq 100 \mathrm{~cm}$ was almost 32 times higher on fenced PRP 1 . Other researches confirmed that deer optimum browsing height is around $100 \mathrm{~cm}$ from the ground level (Renaud et al. 2003; Konôpka \& Pajtík 2015). On unfenced PRP 4 regeneration density was lower even by $62 \%$ compared to fenced PRP 3, but the number of regeneration reached on locality Trčkov only 1,277 recruits ha ${ }^{-1}$. High differences between studied localities can be caused by less favourable stand and habitat conditions for the regeneration, such as adverse relief, dense vegetation cover or higher canopy cover of tree layer (Štícha et al. 2010; Malík et al. 2014; Vacek et al. 2017b). Losses caused by browsing substantially influence the species composition at the cost of fir and rowan (Motta 1996, 2003; Konôpka \& Pajtík 2015), which were completely eliminated on unfenced plots. With heavy damage by game the recruits of beech or spruce reach only one third of the height in comparison with the recruits on fenced PRP. In terms of game species, the main browsing losses are caused by deers compared to wild boards (Ambrož et al. 2015). According to Vrška et al. (2001), despite disputable results the complete fencing of spruce-fir-beech natural forests is currently the only solution ensuring their relatively natural spontaneous development. Similar conclusions were also documented by Olesen \& Madsen (2008) from Denmark and by Harmer (2001) from the United Kingdom, who recommended protecting the natural regeneration in these forests by fencing. In the Alps, Ammer (1996) and Senn \& Sutter (2003) identified the problem of ungulate population densities that were the highest since the $19^{\text {th }}$ century and substantially influenced the dynamics of natural regeneration. Similar problem was observed in Slovakia, where stock of red deer increased by $199 \%$ in period 1960-2013 (Konôpka et al. 2015).
In the Czech Republic number of hunted game increased since 1966 (to 2015) from 63 to 100 thousand heads of roe deer $(+58 \%)$, from 7 to 24 thousand heads of red deer $(+243 \%)$ and especially from 3 to 185 thousand heads of wild boar ( $+6,067 \%$; data FRGMI). On the other hand, the main browsing losses on regeneration are caused by deer compared to wild boards (Ambrož et al. 2015). In details, over last 15 years in Královehradecký region, where Orlické hory Mts. are situated, game stock increased by $17 \%$ for roe deer, by $34 \%$ for red deer and by $89 \%$ for wild boards. In a Natural Forest Area Orlické hory Mts. the highest negative changes since 1980 were observed for wild boards $(+780 \%)$ and then for roe deer (+15\%; Mikeska et al. 1999; data FRGMI, FMI). The highest damage is caused by the high stock of red deer. In February, stock of red deer in study locality regularly amounts to 80 heads per 1,000 ha due to game migrating from Poland, because game is not fed there (Vondřejc 2008). Nevertheless for the successful growth of natural regeneration $5-30$ heads of red deer per 1,000 ha are recommended (Vera 2000). Therefore, the basic principle is a significant reduction of all ungulate species to the ecologically tolerable levels, but this goal is still not fulfilled. The mechanical protection of stands, which reaches up to 50 ha in the Orlické hory Mts., is still a necessary complementary measure. Already in the 1980 s, nature conservation agencies of the Czech Republic acceded to the fencing of the core parts of the reserves, where the ungulate damage to forest stands was far behind tolerable level. This relatively costly fencing measure sought to ensure the successful development of regeneration of tree species threatened by game (Vacek et al. 2012).

\section{Conclusion}

The studied nature reserves belong to the most valuable remnants of natural mixed forests in the area of the Orlické hory Mts. It is advisable to ensure that the dynamics of these richly structured forests with all their specificities would continually take place without any greater anthropogenic disturbances. Research has confirmed a hypothesis about the long-term negative effects of wildlife on structure and development of the studied autochthonous stands. Damage caused by browsing was significant limiting factor for the height growth of natural regeneration. The stands on the unfenced plot were lacking the phase of natural regeneration. With respect to its numbers and tree species composition, mainly fir, rowan and sycamore, were missing. On the contrary, density of recruits was more influenced by habitats and stand conditions than by game browsing.

For the conservation of these valuable forests it is necessary to find efficient methods for the protection of regeneration processes. The basic recommendation is to modify the tree species composition in favour of the abundant natural regeneration of beech and to conse- 
quently protect the admixture of heavily browsed tree species. A certain measures are also the establishment of overwintering enclosure for game or reintroduction of large predators. In many cases the only possible solution is reducing of ungulate populations and additionally long-term protection by fencing. Game management and forestry must be implemented in such a way that there is harmony between them.

\section{Acknowledgments}

This study was supported by the Internal Grant Agency (IGA no. B03/17), Faculty of Forestry and Wood Sciences, Czech University of Life Sciences in Prague.

\section{References}

Ambrož, R., Vacek, S., Vacek, Z., Král, J., Štefančík, I., 2015: Current and simulated structure, growth parameters and regeneration of beech forests with different game management in the Lány Game Enclosure. Lesnícky časopis - Forestry Journal, 61:78-88.

Ammer, C., 1996: Impact of ungulates on structure and dynamics of natural regeneration of mixed mountain forests in the Bavarian Alps. Forest Ecology and Management, 88:43-53.

Bauhus, J., Puettmann, K., Messier, C., 2009: Silviculture for old-growth attributes. Forest Ecology and Management, 258:525-537.

Bebber, D.P., Cole, W.G., Thomas, S.C., Balsillie, D., Duinker, P., 2005: Effects of retention harvests on structure of old-growth Pinus strobus L. stands in Ontario. Forest Ecology and Management, 205:91103.

Bílek, L., Remeš, J., Zahradník, D., 2011: Managed vs. unmanaged. Structure of beech forest stands (Fagus sylvatica L.) after 50 years of development, Central Bohemia. Forest Systems, 20:122-138.

Bílek, L., Vacek, S., Vacek, Z., Remeš, J., Král, J., Bulušek, D., Gallo, J., 2016: How close to nature is close-tonature pine silviculture? Journal of Forest Science, 62:24-34.

Borůvka, L., Podrázský, V., Mládková, L., Kuneš, I., Drábek, O., 2005: Some approaches to the research of forest soils affected by acidification in the Czech Republic. Soil Science \& Plant Nutrition, 51:745749.

Bošela, M., Štefančík, I., Petráš, R. Vacek, S., 2016: The effects of climate warming on the growth of European beechforests depend critically on thinning strategy and site productivity. Agricultural and Forest Meteorology, 222:21-31.

Bulušek, D., Vacek, Z., Vacek, S., Král, J., Bílek, L., Králíček, I., 2016: Spatial pattern of relict beech (Fagus sylvatica L.) forests in the Sudetes of the Czech Republic and Poland. Journal of Forest Science, 62:293-305.

David, F. N., Moore, P. G., 1954: Notes on contagious distributions in plant populations. Annals of Botany of London, 18:47-53.
Clark, P., Evans, F. C., 1954: Distance to nearest neighbour as a measure of spatial relationship in populations. Ecology, 35:445-453.

Cukor, J., Baláš, M., Kupka, I., Tužinský, M., 2017: The condition of forest stands on afforested agricultural land in the Orlické hory Mts. Journal of Forest Science, 63:1-8.

Čavlovič, J., Božič, M., Boncina, A., 2006: Stand structure of an uneven-aged fir-beech forest with an irregular diameter structure: modeling the development of the Belevine forest, Croatia. European Journal of Forest Research, 125:325-333.

Diaci, J., Rozenbergar, D., Boncina, A., 2010: Stand dynamics of Dinaric old-growth forest in Slovenia: Are indirect human influences relevant? Plant Biosystems, 144:194-201.

Ferlin, F., 2002: The growth potential of understorey silver fir and Norway spruce for uneven-aged forest management in Slovenia. Forestry, 75:375-383.

Ficko, A., Poljanec, A., Boncina, A., 2010: Do changes in spatial distribution, structure and abundance of silver fir (Abies alba Mill.) indicate its decline? Forest Ecology and Management, 261:844-854.

Füldner, K., 1995: Strukturbeschreibung in Mischbeständen. Forstarchiv, 66:235-606.

Fürst, C., Vacik, H., Lorz, C., Makeschin, F., Podrázký, V., Janeček, V., 2007: Meeting the challenges of process-oriented forest management. Forest Ecology and Management, 248:1-5.

Götmark, F., 2009: Experiments for alternative management of forest reserves: effects of partial cutting on stem growth and mortality of large oaks. Canadian Journal of Forest Research, 39:1322-1330.

Harmer, R., 2001: The effect of plant competition and simulated summer browsing by deer on tree regeneration. Journal of Applied Ecology, 38:1094-1103.

Hofmeister, Š., Svoboda, M., Souček, J., Vacek, S., 2008: Spatial pattern of Norway spruce and silver fir natural regeneration in uneven-aged mixed forests of northeastern Bohemia. Journal of Forest Science, 54:92-101.

Hopkins, B., Skellam, J. G., 1954: A new method for determining the type of distribution of plant individuals. Annals of Botany, 18:213-227.

Jaehne, S. C., Dohrenbusch, A., 1997: Ein Verfahren zur Beurteilung der Bestandesdiversität. Forstwissenschaftliches Centralblatt, 116:333-345.

Jaworski, A., Kolodziej, Z., Porada, K., 2002: Structure and dynamics of stands of primeval character in selected areas of the Bieszczady National Park. Journal of Forest Science, 48:185-201.

Jorritsma, I. T. M., Van Hees, A. F. M., Mohren, G. M. J, 1999: Forest development in relation to ungulate grazing: a modeling approach. Forest Ecology and Management, 120:23-34.

Klopcic, M., Jerina, K., Boncina, A., 2010: Long-term changes of structure and tree species composition in Dinaric uneven-aged forests: are red deer an important factor? European Journal of Forest Research, 129:277-288. 
Klopcic, M., Boncina, A., 2011: Stand dynamics of silver fir (Abies alba Mill.)-European beech (Fagus sylvatica L.) forests during the past century: a dechne of silver fir? Forestry, 84:259-271.

Knoke, T., Ammer, C., Stimm, B., Mosandl, R., 2008: Admixing broadleaved to coniferous tree species: a review on yield, ecological stability and economics. European Journal of Forest Research, 127:89101.

Konôpka, B., Pajtík, J., 2015: Why was browsing by red deer more frequent but represented less consumed mass in young maple than in ash trees?! Journal of Forest Science, 61:431-438.

Konôpka, J., Kaštier, P., Konôpka, B., 2015: Teoretické východiská a praktické opatrenia na harmonizáciu záujmov lesného hospodárstva a pol'ovníctva na Slovensku. Lesnícky časopis - Forestry Journal, 61:114-123.

Korpel', Š., 1995: Die Urwälder derWestkarpaten. Stuttgart, New York, Gustav Fischer Verlag, 310 p.

Král, J., Vacek, S., Vacek, Z., Putalová, T., Bulušek, D., Štefančík, I., 2015: Structure, development and health status of spruce forests affected by air pollution in the western Krkonoše Mts. in 1979-2014. Forestry Journal, 61:175-187.

Králíček, I., Vacek, Z., Vacek, S., Remeš, J., Bulušek, D., Král, J. et al., 2017: Dynamics and structure of mountain autochthonous spruce-beech forests: impact of hilltop phenomenon, air pollutants and climate. Dendrobiology, 77:121-139.

Kucbel, S., Jaloviar, P., Saniga, M., Vencurik, J., Klimaš, V., 2010: Canopy gaps in an old-growth fir-beech forest remnant of Western Carpathians. European Journal of Forest Research, 129:249-259.

Liira, J., Sepp, T., Kohv, K., 2011: The ecology of tree regeneration in mature and old forests: combined knowledge for sustainable forest management, Journal of Forest Research, 16:184-193.

Lindenmayer, D. B., Franklin, J. F., 2002: Conserving Forest Biodiversity. A Comprehensive Multiscaled Approach. Island Press, Washington, DC, $351 \mathrm{p}$.

Linder, P., Östlund, L., 1998: Structural changes in three midboreal Swedish forest landscapes, 1885 - 1996. Conservation Biology, 85:9-19.

Lindh, B. C., Muir, P. S., 2004: Understory vegetation in young Douglas-fir forests: does thinning help restore old-growth composition? Forest Ecology and Management, 192:285-296.

Malík, K., Remeš, J., Vacek, S., Štícha, V., 2014: Development and dynamics of mountain spruce (Picea abies [L.] Karsten) stand regeneration. Journal of Forest Science, 60:61-69.

Mattila, M., Kjellander, P., 2017: The tree species matrix, influence on the level of herbivore browsing in mixed forest stands in southwest Sweden. Scandinavian Journal of Forest Research, 32:1-5.

Mazancourt, C., Isbell, F., Larocque, A., Berendse, F., Luca, E., Grace, J. B. et al., 2013: Predicting ecosystem stability from community composition and biodiversity. Ecology Letters, 16:617-625.
Meier, M., Stöhr, D., Walde, J., Tasser, E., 2017: Influence of ungulates on the vegetation composition and diversity of mixed deciduous and coniferous mountain forest in Austria. European Journal of Wildlife Research, 63:29.

Menhinick, C. F., 1964: A comparison of some speciesindividuals diversity indices applied to samples of field insects. Ecology, 45:859-861.

Motta, R., 1996: Impact of wild ungulates on forest regeneration and tree composition of mountain forests in the Western Italian Alps. Forest Ecology and Management, 88:93-98.

Mikeska M. et al., 1999: Oblastní plán rozvoje lesů PLO - 25 Orlické hory. ÚHÚL Brandýs nad Labem - pobočka Hradec Králové, 224 p.

Motta, R., 2003: Ungulate impact on rowan (Sorbus aucuparia L.) and Norway spruce (Picea abies (L.) Karst.) height structure in mountain forests in the eastern Italian Alps. Forest Ecology and Management, 181:139-150.

Mountford, M. D., 1961: On E. C. Pielou's index of nonrandomness. Journal of Ecology, 49:271-275.

Nilsson, S. G., Niklasson, M., Hedin, J., Aronsson, G., Gutowski, J. M., Linder, P. et al., 2002: Densities of large living and dead trees in old-growth temperate and boreal forests. Forest Ecology and Management, 161:189-204.

Olesen, C. O., Madsen, P., 2008: The impact of roe deer (Capreolus capreolus), seedbed, light and seed fall on natural beech (Fagus sylvatica) regeneration. Forest Ecology and Management, 255:3962-3972.

Paluch, J.G., 2007: The spatial pattern of a natural European beech (Fagus sylvatica L.) - silver fir (Abies alba Mill.) forest: A patch mosaic perspective. Forest Ecology and Management, 253:161-170.

Pantič, D., Medarevič, M., Bankovič, S., Obradovič, S., Šlujkič, B., Pešič, B., 2011: Structural, production and dynamic characteristics of the strict forest reserve Račanska Šljivovica“ on Mt. Tara. Bulletin of the Faculty of Forestry, 103:93-114.

Petráš, R., Pajtík, J., 1991: Sústava česko-slovenských objemových tabuliek drevín. Lesnícký časopis, 37:49-56.

Pielou, E. C., 1959: The use of point-to-plant distances in the study of the pattern of plant populations. Journal of Ecology, 47:607-613.

Pielou, E. C., 1975: Ecological diversity $-1^{\text {st }}$ Ed. New York, Wiley, $165 \mathrm{p}$.

Pretzsch, H., 2001: Modellierung des Waldwachstums. Berlin, Parey Buchverlag, 341 p.

Remeš, J., Bílek, L., Novák, J., Vacek, Z., Vacek, S., Putalová, T., Koubek, L., 2015: Diameter increment of beech in relation to social position of trees, climate characteristics and thinning intensity. Journal of Forest Science, 61:456-464.

Renaud, P. C., Dumont, B., Verheyden-Tixier, H., 2001: Do foliage high and structure of saplings affect feeding preferences of red deer Cervus elaphus? In: International Conference Conference on Forest Dynamics and Ungulate Herbivory. Davos, Switzerland, p. 236-348. 
Ripley, B. D., 1981: Spatial statistics. ${ }^{\text {st }}$ Ed. New York, John Wiley \& Sons, 252 p.

Saniga, M., 1999: Štruktúra, produkčné a regeneračné procesy Dobročského pralesa. Zvolen, Technická univerzita: $64 \mathrm{p}$.

Saniga, M., Zrak, J., Pittner, J., Balanda, M., 2013: Štruktúra, produkcia, regeneračné procesy a disturbačný režim prírodného lesa v NPR Skalná Alpa. Zvolen, Technická univerzita, 68 p.

Senn, J., Suter, W., 2003: Ungulate browsing on silver fir (Abies alba) in the Swiss Alps: Beliefs in search of supporting data. Forest Ecology and Management, 181:151-164.

Seymour, R. S., Hunter, M. L., 1999: Principles of ecological forestry. In: Hunter, M. L. (ed.): Maintaining Biodiversity in Forested Ecosystems. Cambridge Univ. Press, Cambridge, p. 22-61.

Shannon, C. E., 1948: A mathematical theory of communications. Bell System Technical Journal, 27:379423.

Schulze, E. D., Bouriaud, O., Wäldchen, J., Eisenhauer, N., Walentowski, H., Seele, C. et al. 2014: Ungulate browsing causes species loss in deciduous forests independent of community dynamics and silvicultural management in Central and Southeastern Europe. Annals of Forest Research, 57:267-288.

Splechtna, B. E., Gratzer, G., Black, B. A., 2005: Disturbance history of a European old-growth mixedspecies forest - A spatial dendro-ecological analysis. Journal of Vegetation Science, 16:511-522.

Suzuki, M., Miyashita, T., Kabaya, H., Ochiai, K., Asada, M., Kikvidze, Z., 2013: Deer herbivory as an important driver of divergence of ground vegetation communities in temperate forests. Oikos, 122:104-110.

Szwagrzyk, J., Czerwczak, M., 1993: Spatial patterns of trees in natural forests of East Central Europe. Journal of Vegetation Science, 4:469-476.

Šebková, B., Šamonil, P., Janík, D., Adam, D., Král, K., Vrška, T. et al., 2011: Spatial and volume patterns of an unmanaged submontane mixed forest in Central Europe: 160 years of spontaneous dynamics. Forest Ecology and Management, 262:873-885.

Štefančík, I., 2006: Changes in tree species composition, stand structure, qualitative and quantitative production of mixed spruce, fir and beech stand on Stará Píla research plot. Journal of Forest Science, 52:74-89.

Štefančík, I., Vacek, S., Podrázský, V., Klouček, T., 2014: Kvantitatívna produkcia bukovej (Fagus sylvatica L.) žŕdkoviny v oblasti Vihorlatských vrchov. Zprávy lesnického výzkumu, 59:198-204.

Štícha, V., Kupka, I., Zahradník, D., Vacek, S., 2010: Influence of micro-relief and weed competition on natural regeneration of mountain forests in the Šumava Mountains. Journal of Forest Science, 56:218-224.

Tabaku, V., 2000: Struktur von Buchen-Urwäldern in Albanien im Vergleich mit deutschen Buchen-Naturwaldreservaten und Wirtschaftswäldern. Cuvillier Verlag, Göttingen.

Vacek, S., Černý, T., Vacek, Z., Podrázský, V., Mikeska, M., Králíček, K., 2017a: Long-term changes in vegetation and site conditions in beech and spruce forests of lower mountain ranges of Central Europe. Forest Ecology and Management, 398:75-90.
Vacek, S., Moucha, P. et al., 2012: Péče o lesní ekosystémy v chráněných územích ČR. Praha, Ministerstvo životního prostředí, 896 p.

Vacek, S., Vacek, Z., Bílek, L., Nosková, I., Schwarz, O., 2010: Structure and development of forest stands on permanent research plots in the Krkonoše Mts. Journal of Forest Science, 56:518-530.

Vacek, S., Vacek, Z., Bulušek, D., Bílek, L., Schwarz, O., Simon, J., Stícha, V., 2015: The role of shelterwood cutting and protection against game browsing for the regeneration of silver fir. Austrian Journal of Forest Science, 132:81-102.

Vacek, S., Vacek, Z., Podrázský, V., Bílek, L., Bulušek, D., Štefančík, I. et al., 2014b: Structural Diversity of Autochthonous Beech Forests in Broumovske Stěny National Nature Reserve, Czech Republic. Austrian Journal of Forest Science, 131:191-214.

Vacek, Z., Vacek, S., Remeš, J., Štefančík, I., Bulušek, D., Bílek, L., 2013: Struktura a vývoj lesních porostů v NPR Trčkov - CHKO Orlické hory, Česká republika. Lesnícky časopis - Forestry Journal, 59:249-264.

Vacek,Z., Vacek, S., Bílek, L., Král, J., Remeš, J., Bulušek, D. et al., 2014a: Ungulate Impact on Natural Regeneration in Spruce-Beech-Fir Stands in Černý důl Nature Reserve in the Orlické Hory Mountains, Case Study from Central Sudetes. Forests, 5:2929-2946.

Vacek, Z., Vacek, S., Bílek, L., Remeš, J., Štefančík, I., 2015: Changes in horizontal structure of natural beech forests on an altitudinal gradient in the Sudetes. Dendrobiology, 73:33-45.

Vacek, Z., Bulušek, D., Vacek, S., Hejcmanová, P., Remeš, J., Bílek, L. et al., 2017b: Effect of microrelief and vegetation cover on natural regeneration in European beech forests in Krkonoše national parks (Czech Republic, Poland). Austrian Journal of Forest Science, 134:75-96.

Vrška, T., Adam, D., Hort, L., Kolár, T., Janík, D., 2009: European beech (Fagus sylvatica L.) and silver fir (Abies alba Mill.) rotation in the Carpathians - a developmental cycle or a linear trend induced by man? Forest Ecology and Management, 258:347-356.

Vera, F. W. M., 2000: Grazing ecology and forest history. CABI Publishing, Oxon. 506 p.

Vondřejc, M., 2008: Myslivost na majetcích Kristiny Colloredo-Mansfeldové. In: Listnaté porosty a Natura 2000. Vysoké Chvojno, p. 39-45

Vrška, T., Hort, L., Odehnalová, P., Adam, D., Horal, D., 2001: Boubín virgin forest after 24 years (19721996) - deveplopment of tree layer. Journal of Forest Science, 47:439-456.

Zeibig, A., Diaci, J., Wagner, S., 2005: Gap disturbance patterns of a Fagus sylvatica virgin forest remnant in the mountain vegetation belt of Slovenia. Forest Snow and Landscape Research, 79:69-80.

Zielonka, T., Holeksa, J., Fleischer, P., Kapusta, P., 2010: A tree-ring reconstruction of wind disturbances in a forest of the Slovakian Tatra Mountains, Western Carpathians. Journal of Vegetation Science, 21:3142. 